$\S=-1$

\title{
The Registration Process of Industrial Property Rights
}

\author{
Deswita Rosra \\ Faculty of Law, Bung Hatta University \\ *Corresponding author E-mail: deswitarosra16@gmail.com
}

\begin{abstract}
The objective of this article is to determine the registration process of industrial property rights. This research uses normative law method, which is a qualitative research method utilizing content analysis of secondary data. In general, the registration process of industrial property rights is by submitting the application to Directorate General of Industrial Property Rights (DJHKI) in writing in Bahasa Indonesia through filling the application form with full identities of the applicant. The application is signed by the applicant or the proxy (holder of authority) along with the attachments of the industrial property rights which are applied to the registration. The registration process of industrial property rights also has different special provisions. The research results show that the registration process of industrial property rights is regulated under Intellectual Property Rights Law and has been in conformity with International Convention.
\end{abstract}

Keywords: Industrial Property Rights, Proxy, Registration.

\section{Introduction}

Industrial property rights play important role in the business world, and industrial property rights is a part of intellectual property rights. The term intellectual property rights consist of the word rights, property and intellectual, where the word property is the abstraction which can be owned, transferred, purchased, or sold. The intellectual property is the property of all human intellectual works such as technology, knowledge, art, humanities, song composition, writings, caricature, and other stuff which bring benefits to human. The works which are created from the human intellectual ability or from ideas through copyright works with commercial value shall get legal protection by the country to an individual, a group or institution owning the tangible works, by registering their intellectual properties.

The system of intellectual property rights is private rights, where anybody is welcomed to submit the application of their intellectual property. Exclusive right given by the country to an individual with property rights (inventor, creator, designer, and others) is intended as appreciation to their creativity (through the works) and to encourage other people to continue developing more inventions, so that by the intellectual property rights, the interests of society is determined by means of the markets (1).

World Intellectual Property Organization (WIPO) is an international agency charged with Intellectual Property Rights issues. WIPO is a part of United Nation agencies and Indonesia is one of the members. WIPO plays the role to arrange the regulation and international system in Intellectual Property Rights protection. Engaging many countries makes WIPO become an international regime in Intellectual Property Rights protection, while the objective of WIPO is to encourage creativity and to promote the protection for intellectual property to all over the world (2).

That is why human Intellectual Property Rights protection conducted through registration. The registration process is performed based on the requirements defined in the regulations, where internationally, it is found in Paris Convention and Bern Convention and nationally, it is found in Government Regulation on Intellec- tual Property: Law No. 25 of 2014 on Copy Rights, No. 14 of 2001 on Patents, No. 15 of 2001 on Brands, No. 30 of 2000 on Trade Secrets, No. 31 of 2000 on Industrial Design, No. 32 of 2000 on Integrated Circuit Layout Design and No. 29 of 2000 on Protection of Plant Variety (3). The main objective of the registration is to obtain the guarantee and protection upon the ideas through the works from a human.

With the existence of Intellectual Property Rights, human creativity can be well-documented and protected by the law. This is a way to avoid any form of piracy, plagiarism, fraud, and even counterfeiting. The law that regulates the property rights generally has territorial feature, the registration or the enforcement of Intellectual Property Rights must be conducted separately in each of the corresponding jurisdictions. The protected intellectual property rights in Indonesia is the one that has been registered in the country (1).

The awareness among Indonesian to register for their IPR is considered low, whereas the registration of intellectual property rights is a crucial thing in order to obtain legal protection. This causes the rise of violation of Intellectual Property Rights, especially in Science and Technology fields. Many research products still have not got patent rights that leading to the plagiarism and piracy. Same goes on brand rights, where the registered brands are not under the original owner of the brand itself. Plagiarism and piracy are rampant in society (4).

\section{Literature Review}

As the increasing of violation toward industrial property rights, such as piracy, counterfeiting, infringement, and other violations regarding industrial property rights, it is causing the loss for business people, legal owners of intellectual property, consumers, and market mechanisms will be disturbed by the violation to industrial property rights.

The main issue happened in Indonesia is the violation of copyrights, as it is more frequent than other forms of violation on IPR. One kind of violation against copyrights is piracy, which is a high 
IPR offense and Indonesia becomes the fourth country on the high rate of piracy against Intellectual Property Rights (51\%) (5).

With the role of industrial or intellectual property rights and the proper documentation of any type of human creativity, it is possible to avoid producing identical technologies or other works. The proper documentation is expected to make the society get maximum benefit for their life necessities or further developments and give higher additional value (1).

Therefore, it is obligatory to register for industrial or intellectual property rights for running a safer business, producing better and more creative works, and motivating, so that the registration of Intellectual Property Rights is important. There is clear and certainty of law for the registration, where intellectual property rights protection is not automated and rights comes after registration. Intellectual Property Rights is documented because of registration. The business in goods and services is protected after the registration done. Appreciating people creation is a political and noble attitude. Then, societies are able to share a sense of belonging on enjoying literature works.

\section{Research Method}

This method used in this research is normative law research. Normative law research is a method or a way used in a legal research by reviewing existing references (6). Using secondary data means the data are obtained from literature reviews, which consist of books and laws. The secondary data consist of:

1) Primary Legal Materials are authorized legal materials that bind or make people obedient to the law, such as laws and regulations and judge's verdict. In this article, laws concerning intellectual property rights and international convention are used as primary materials;

2) Secondary Legal Materials are legal materials about the explanation of primary legal materials, such as books, papers, newspaper articles, magazines and internet; and

3) Tertiary Legal Materials are the materials that are supporting the primary and secondary legal materials, such as Blacks Law Dictionary and Encyclopedia.

Data collecting technique is used by studying the documents and analyzing the data qualitatively. Analyzing data qualitatively means grouping the data based on researched aspects, without using numbers but using researched government regulations as the basis.

\section{Results and Discussion}

The registration of industrial property rights or intellectual property rights aims to obtain legal assurance and protection of the law against the intellectual property rights. The registration process of intellectual property rights starts from the preparation of documents of requirements. The request can be filed on behalf of the individual, some people or legal entity. The request is submitted to Directorate General of Industrial Property Rights (DJHKI) through the office of Department of Law and Human Rights throughout Indonesia. The applicant is asked to fill the application form for registration. The registration process of intellectual property rights in general (1) are:

\subsection{Patent}

Patent application should be submitted as soon as possible, to take in mind that the patent system in Indonesia adheres to the system of first-to-file, which is a system of patent granting with the mechanism that someone who first proposed the application is considered as the patent holder when all the requirements are met. The terms of this system is arranged in Article 34 of Patent Law. The stages to be passed in a patent application are the submission of the application, administrative screening, announcement of application patents, substantive screening, and granting or denial of patents. The registration process of patent are: a. Submitting patent application in writing in Bahasa Indonesia prepared in 4 copies to Directorate General of Industrial Property Rights

b. The application form for patent requesting should contain:

1. Date, month, and year of request

2. Full and clear address of applicant

3. Full name and nationality of inventor

4. Full name and address of the proxy (if the patent is requested through the proxy)

5. Special letter of authority in case the application is filled by the proxy

6. The application statement to be given patent

7. Title of invention

8. Claim contained in the invention

9. Description of invention, completely contains the explanation of the process of invention

10. Picture mentioned in the description if needed to explain the invention

11. Abstract of invention

c. Further condition about the procedures of request is regulated in Government Regulation.

Patent application can be filed by visiting DJHKI, through the office of the Department of Law and Human Rights throughout Indonesia. In case the application meets the requirements, DJHKI will notify the approval or the denial of patent application. The approval or denial of application of regular patent is about 36 (Thirty Six) months from the date of application submission and 24 (twenty four) months for application of simple patent, and $\mathrm{Pa}$ tent Certificate will be issued as a proof on the rights of the patents.

\subsection{Brands}

Brands have a significant role in economic life, especially in the world of trade in goods and services to comprehend with other products. Brand is also an important aspect of a business and is a hallmark of a product that will become the identity and be remembered by business and society. For that reason, the brand registration shall be done since the beginning of the business, because as the business runs, the more risk of fraud and plagiarism appear to harm the business (7).

There are two systems in brand registration: declarative system (first to use) means the system where emphasis placed on the first user, the one who first wear a brand is considered by the law as the owner of the brand, and constitutive system (first to file) means whoever registering first, the registration is accepted without questioning whether the registrant actually uses the brand for the benefit of their business, in other words the registration of a brand will be given to the first party who do the registration of the brand. The registration process of a brand are:

1. The application is submitted in writing in Bahasa Indonesia, the form is made in 4 copies to DJHKI by including:

a. Date, month, and year

b. Full name, nationality, and address of the applicant

c. Full name and address of the proxy if the patent is requested through the proxy

d. Colors, if the brand contain colors

e. Name of country and the first brand requesting date if the application is submitted with priority rights

f. Sample of brand/brand ethics, brand ethics colors, meaning of foreign languages/letters/numbers and the pronunciation, goods/services class, good/services type

2. The application is signed by the applicant or proxy

3. The applicant as mentioned in point 2 can be a person or a number of people or law entity

4. The application is attached with registration fee receipt

5. In case the application is submitted by more than one applicant who have rights on the brand at one time, all applicant names are included and one address is chosen to be submitted 
6. In case the application referred to in point 5 , the application is signed by one of the applicants entitled to the brand by attaching a written approval of the represented applicant

7. In case the application referred to in point 5 is filled by its proxy, the letter of authority shall be signed by all parties entitled to the brand

8. The proxy as referred in point 7 is the Consultant of Intellectual Property Rights

9. The conditions concerning the requirements to be appointed as Consultant of Intellectual Property Rights shall be regulated by a Government Regulation, while the procedure of appointment shall be regulated by a Presidential Decree.

After the registration documents are received by Directorate General of Intellectual Property Rights, several inspection steps are conducted until the publication of the brand certificate: the formality examination, substantive examination, announcement and objection and re-examination of the announced application. Approved applications are registered in the General register of Brands. DJHKI shall issue and grant the Brand Certificate to the applicants or their proxy within 30 (Thirty) days from the date of application.

\subsection{Industrial Design}

An industrial design which receives protection is a new industrial design and is not against the applicable regulation, public order, religion or morals. Industrial design rights are granted on an application basis. The registration process of industrial design is as follows:

1. The application shall be submitted in writing in Bahasa Indonesia to Directorate General of Industrial Property Rights by paying fees as stipulated in the regulation

2. The application referred to in point 1 shall be signed by the applicant or his/her proxy

3. The application shall include:

a. Date, month, and year of application

b. Name, full address, and nationality of design

c. Name, full address, and nationality of applicant

d. Full name and address of proxy if the application is submitted through the proxy

e. Name of country and the date of the first application submission, in case the application is submitted with priority rights

4. The application as referred to point 3 is attached with:

a. Physical sample or picture, or photo and the description of the industrial design applied for registration

b. Special letter of authority, if the application is submitted by proxy

c. A declaration that the industrial description applied for registration are the property of the applicant or the designer

5. In case the application is submitted by more than one applicant who has rights on the brand at one time, the application shall be signed by one of the applicants by attaching the written approval of other applicants

6. In case the application is submitted by non-designer, the application shall be attached with the statement and sufficient evidence that the applicant has the rights on the concerned industrial design

7. The conditions concerning the procedures of application are further regulated in Government Regulation.

The examination of industrial design documents submitted to Directorate General of Industrial Property Rights shall be conducted by inspection, announcement, substantive examination, granting of industrial design rights and rejection of industrial design rights. A qualified application is announced by Directorate General of Industrial Property Rights by placing in on a special facility which is easily and clearly seen by the public, no later than 3 (Three) months from the date of receipt.

\subsection{Layout Design of Integrated Circuit}

The integrated circuit layout design which receives protection is the original one, not a common object of the designers and not conflicted with the existing regulations, public orders, religions, or morals. The rights of integrated circuit layout design is given on the application basis. The registration process of integrated circuit layout design is as follows:

1. The application shall be submitted in writing in Bahasa Indonesia to Directorate General of Industrial Property Rights by paying fees as stipulated in the regulation

2. The application referred to in point 1 shall be signed by the applicant or his/her proxy

3. The application shall include:

a. Date, month, and year of application

b. Name, full address, and nationality of design

c. Name, full address, and nationality of applicant

d. Full name and address of proxy if the application is submitted through the proxy

e. Name of country and the date of the first exploiting commercially, in case layout design has ever been exploited before the application is submitted

4. The application as referred to point 3 is attached with:

a. Copy of picture or photo and description of the integrated circuit layout design applied for registration

b. Special letter of authority, in case the application is submitted by proxy

c. A declaration that the layout design of integrated circuit applied for registration is the applicant property

d. A letter that explaining the date as referred to point 3 letter e

5. In case the application is submitted by more than one applicant who have rights on the brand in one time, the application shall be signed by one of the applicants by attaching the written approval of other applicants

6. In case the application is submitted by non-designer, the application shall be attached with the statement and sufficient evidence that the applicant has the rights on the concerned layout design of integrated circuit

7. The conditions concerning the procedures of application are further regulated in Government Regulation.

The check for the completeness of requirements on the registration of integrated circuit layout design shall be conducted by administrative check (formality check), if the requirements are fulfilled, then Directorate General of Industrial Property Rights will grant the rights and post in General List of Layout Design of Integrated Circuit, and also announce it in Official News of Layout Design of Integrated Circuit.

\subsection{Trade Secrets}

The protection scope of trade secrets includes production method, processing method, marketing method or other information in technology and/or business which has economic value and unknown to the public. The registration process of trade secrets is not necessary because the Constitution directly protects the trade secrets if the information is classified, has economic values and kept confidential through proper efforts. Trade secrets license must be listed to Directorate General of Industrial Property Rights and the office of Department of Law and Human Rights.

\subsection{Plant Varieties Protection}

In the implementation of plant varieties protection legislation, it is expected that the role of institutions or agencies within the scope of Ministry of Agriculture to perform its roles and functions to provide adequate legal protection on new plant varieties. The new plant varieties which receive legal protection shall be the one that meets the criteria: new, unique, uniform, stable, and has been named. However, not all plant varieties get the plant varieties protection, like the one that contradicts with government policies, 
public orders, morals, religions, health, and environmental sustainability.

Plant varieties are considered new when the time of application for registration is submitted, the plant has not been traded or if it has been traded with the condition of the plant has been in Indonesia for 1 (One) year, while in overseas for 4 (Four) years for the seasonal plant and 6 (six) years for the annual plant (8). The registration process of plant varieties protection is carried out by Article 11 on Law No. 29 of 2000 as follows:

1. The application of plant varieties protection rights is submitted to the office of Plant Varieties Protection (PVP) in writing in Bahasa Indonesia by paying fees as stipulated by the Minister

2. The application letter of PVP rights shall include:

a. Date, month, and year of application

b. Full name and address of the applicant

c. Full name, address, and nationality of the breeder as well as the name of the designated heir

d. Varieties name

e. Varieties description including the origin or genealogy, morphology characteristics, and other important features

f. Picture and/or photo mentioned in the description, if necessary for making the description clearer

3. In case of application, PVP rights is submitted by:

a. Person or legal entity as the proxy of applicant shall be accompanied the letter of authority with the name and full address of the rightful authorization

b. The heirs shall be accompanied by the evidence of heirs

4. In case of transgenic varieties, the description shall also include the molecular explanation of the relevant varieties and genetic stability of the proposed properties, the parent's reproductive system, the presence of its wild relative, the content of the compound which may interfere with the environment and human health and the guide to destruction if some deviation occurs, accompanied by a letter of statement to the environment and human health of the authorized institution

5. The condition on the application of PVP rights shall be further regulated by the government.

The completeness checking of PVP rights application requirements shall be made by announcement, substantive examination, granting or rejection of PVP rights application. The PVP office decides to grant or reject the PVP rights no later than 24 (TwentyFour) months from the date of substantive examination and PVP rights is granted in PVP rights Certificate, listed in General List of PVP and announced in Official News of PVP (Article 34 of Law on PVP).

\section{Conclusions and Recommendation}

The registration process of the Industrial Property Rights must be done in line with the terms that have been recognized as the intellectual property rights. With the registration of the properties, there is law protection toward the ideas produced by human inventions or intellectual abilities.

The registration of Intellectual Property Rights is a very important aspect to obtain legal protection of human work and knowledge. The term has been regulated under national laws and regulations and has been in conformity with international laws. The registration process of Industrial Property Rights shall use the requirements of admitted intellectual property rights. The registration process of patent, brand, industrial design, integrated circuit layout design, plant variety is conducted by submitting the application to DJHKI in writing in Bahasa Indonesia through the application form filling with full identities of the applicant or the proxy along with the attachments for registration of industrial property rights. Subsequently, a sequence of processes is conducted, from administrative check, substantive examination, and rejection or denial of the rights. The certificate of rights will be issued if the requirements are fulfilled and the property will be listed in General List and announced in Official News. For trade secrets, there is no need for registration because the Constitution has directly protected the trade secrets.

Society has low interest in registering their Intellectual Property Rights. This has become a challenge in the practice of intellectual property rights registration. We expect the government to promote more about the importance of this process of registration, so the awareness of society for registering their intellectual property rights will increase and they will be able to obtain legal protection on their properties. This action can avoid piracy, plagiarism, fraud, and even counterfeiting of human intellectual works.

\section{Conflict of Interest}

There is no conflict of interest regarding the discussion of this research.

\section{References}

[1] Guide Book of Intellectual Property Rights. 2007. Directorate General of Intellectual Property Rights. Department of Law and Human Rights Republic of Indonesia

[2] WIPO. 2008. International Regime for Intellectual Property Rights Protection in International Delegation Concept. strikingbrainware.blogspot.com, cited on Friday, May 18, 2018, 11.45 (GMT+7) The Registration Process of Industrial Property Rights

[3] Rosra, D. (2015). Lecturer Notes on Intellectual Property Rights. Faculty of Law. Bung Hatta University Padang

[4] Novanifqiawansyah. 2012. Appreciating The Importance of Intellectual Property Rights. Novanifqiawansyah.blogspot.com, cited on Monday, December 4, 2017, 20.00 (GMT+7)

[5] Liputan 6. 2016. Violation against Intellectual Property Rights. htpp://www.liputan6.com, cited on Monday, May 14, 2017, 20.45 $(\mathrm{GMT}+7)$

[6] Soekanto, Soerjono and Sri Mamudji. 2009. Normative Law Research: A Brief Review. $11^{\text {th }}$ print. PT Raja Grafindo Persada: Jakarta

[7] The Law on Protection of Intellectual Property Rights. 2011. $1^{\text {st }}$ print. Anfaka Perdana: Surabaya.

[8] Afief, D.Z. (2016). Group V paper about Plant Varieties Protection. Faculty of Law. Bung Hatta University Padang 